\title{
Entrepreneurial Skills in Snail Production Required by Youths for Wealth Creation in Enugu State, Nigeria
}

\author{
Onah Ogechukwu ${ }^{1}$, Gideon Nwabueze Monday ${ }^{2, *}$, Ifeanyieze F. O ${ }^{1}$, Ekenta Lilian Ukamaka ${ }^{1}$, \\ F. N. Ezebuiro ${ }^{1}$, Nwankwo Clara Ukamaka ${ }^{1}$, Ogbonnaya Elom ${ }^{3}$, V. C. Asogwa ${ }^{4}$, Francis N. Azunku ${ }^{3}$, \\ E. C. Isiwu ${ }^{2}$ \\ ${ }^{1}$ Department of Agricultural Education, Faculty of Vocational and Technical Education, University of Nigeria, Nsukka, Nigeria \\ ${ }^{2}$ Department of Agricultural/Home Science Education, Michael Okpara University of Agriculture, Umudike, Nigeria \\ ${ }^{3}$ Department of Agricultural Education, Ebonyi State College of Education, Ikwo, Nigeria \\ ${ }^{4}$ Department of Agricultural Education and Extension, Faculty of Agriculture, University of Eswatini, Eswatini
}

Received February 4, 2021; Revised August 11, 2021; Accepted September 8, 2021

\section{Cite This Paper in the following Citation Styles}

(a): [1] Onah Ogechukwu, Gideon Nwabueze Monday, Ifeanyieze F. O, Ekenta Lilian Ukamaka, F. N. Ezebuiro, Nwankwo Clara Ukamaka, Ogbonnaya Elom, V. C. Asogwa, Francis N. Azunku, E. C. Isiwu, "Entrepreneurial Skills in Snail Production Required by Youths for Wealth Creation in Enugu State, Nigeria," Universal Journal of Agricultural Research, Vol. 9, No. 5, pp. 208 - 220, 2021. DOI: 10.13189/ujar.2021.090508.

(b): Onah Ogechukwu, Gideon Nwabueze Monday, Ifeanyieze F. O, Ekenta Lilian Ukamaka, F. N. Ezebuiro, Nwankwo Clara Ukamaka, Ogbonnaya Elom, V. C. Asogwa, Francis N. Azunku, E. C. Isiwu (2021). Entrepreneurial Skills in Snail Production Required by Youths for Wealth Creation in Enugu State, Nigeria. Universal Journal of Agricultural Research, 9(5), 208 - 220. DOI: 10.13189/ujar.2021.090508.

Copyright $\odot 2021$ by authors, all rights reserved. Authors agree that this article remains permanently open access under the terms of the Creative Commons Attribution License 4.0 International License

\begin{abstract}
The study identified entrepreneurial skills in snail production required by youths for wealth creation in Enugu state, Nigeria. A descriptive survey research design was adopted in the study. Researchers employed a multistage sampling technique in the selection of respondents in the study. The sample size of the study was two hundred and sixteen (216) youths who are into snail farming. Data were voluntarily collected from respondents through the use of an adapted structured questionnaire titled "Snail Production Skill Questionnaire" (SPSQ). Data collected for the study were analyzed using descriptive statistics such as mean and standard deviation. The study identified 15 entrepreneurial skills in selecting and constructing a snail pen, 19 entrepreneurial skills in breeding and feeding of snails, 14 entrepreneurial skills required by youths in routine management practices, 11 entrepreneurial skills required by youths in prevention and control of pests and diseases and 13 entrepreneurial skills required by youths in harvesting, processing and marketing of snails for snail production in Enugu state. It was recommended among others that Agricultural extension agents in collaboration with community leaders in Enugu state should organize a workshop to educate jobless and underemployed youths on the entrepreneurial skills in snail
\end{abstract}

production identified by this study for wealth creation.

Keywords Land Snails, Snail Production, Entrepreneurial Skills, Snail Breeding, Feeding of Snails and Routine Management Practices

\section{Introduction}

The conventional sources of animal protein to the people of Enugu state in Nigeria are mostly cattle goat, sheep, pig, poultry, fish among others. However, there are other sources which are yet to be fully tapped but have great potentials for development and income generation. Snail is one of such. Snails are small bodied animals belonging to the phylum Mollusca and class Gastropoda. They are bilaterally symmetrical and lack backbones (invertebrates) but usually protected by calcium carbonate-containing exoskeleton (calcerous shell). Most snail species are hermaphrodites and the largest, common, productive and edible land snail is Achatina achatina (the Giant African Snail) which is being recommended by most farmers in Nigeria for snail farming, though others 
such as Achatina achatina and Achatina fulica are still very common and good for breeding $[25,3,7,1]$. More so, [22] stated that snail meat has been a major foodstuff and protein source in the diet of people residing in high rain forest zone of Nigeria like Enugu state and others. Snail farming is very lucrative; however, it has not been fully leveraged by farmers for wealth creation. Researchers perceive that this may be due to the fact that majority of the farmers may lack required entrepreneurial skills in this area of farming.

Indisputably, the effective management of snail business for wealth creation requires the possession of certain entrepreneurial skills by entrepreneurs. Entrepreneurial skills are those learned capabilities possessed by an entrepreneur which will enables him carry out predetermined results often with the minimum outlay of time, energy or both. It is the ability to manipulating input resources effectively with a particular enterprise to achieve the production growth [17]. More so, [17] argued that if an entrepreneur is one who starts, organizes and manages an enterprise, then entrepreneurial skill is the necessary capabilities an entrepreneur needs to successfully run an enterprise [6]. In the context of this study, [10] grouped entrepreneurial skills in snail production under two areas namely; vocational and technical, and business management skills. Entrepreneurial skills in snail production can therefore be referred to as all mental and physical abilities required by farmers in order to plan, implement, coordinate and evaluate snail enterprise for wealth creation and self-reliance. It could be conceptualized as a set of skills required by farmers to take up snail farming as a vocation for income generation [26]. Though there has been recent awakening to snail farming business in different parts of Nigeria; researchers observed that one of the reasons why it is yet to fully thrive is that most farmers in Enugu state are still bent on practicing wild snail production (WSP). More so, [23] observed that a widespread participation in snail production is yet to be achieved in Enugu state, Nigeria. This could probably be as a result of entrepreneurial incompetency of the farming populace in snail domestication [20]. The wild snail population has decreased over the years, as a result of the effect of man's activities such as felling of vegetations, bush burning and overexploitation of this animal resource, stemming from teaming population. Hence, the few remnants of the species of land snails are harvested before they reach maturity period $[8 ; 13]$. Consequently, few people are beginning to domesticate and breed snails in Enugu state. Unfortunately, most youths especially in Enugu state, Nigeria, still have it as a habit to hunt for snails without considering how they can be domesticated, multiplied and maintained for steady supply at local and international markets since its demand is high even amidst crude poverty and employment level in the state.

\subsection{Statement of the Problem}

Snail rearing requires relatively little capital to start up, thus it can be greatly harnessed by poor unemployed youths for wealth creation in Enugu state, Nigeria. However, due to ignorance in snail production skills among youths, snails mostly sold in the market are largely collected from the wild by households. This evidently contributes to the observed low and seasonal supply of snails and snail meats in various markets. It has therefore become necessary to domesticate snails and organize snail farming into a viable enterprise that has the potentials of supplementing the protein need for humans and also for an alternative source of income in the long run especially in the face of present economic hardship in Nigeria, yet there seems to be dearth of literatures adequately addressing this issue in Enugu state. Addressing this issue through research would provide youths, educationists, entrepreneurs and government with empirical information on entrepreneurial skills for snail production in Enugu state. Also, youths through the information provided by this study would be spurred to venture in snail farming enterprise. More so, the findings of this study would form an entrepreneurial-skill-package (ESP) for government and educationists in Enugu state. Hence, the study seeks to identify entrepreneurial skills in snail production required by youths for wealth creation in Enugu state.

\subsection{Specific Objectives}

Specifically, the study sought to identify entrepreneurial skills required by youths in:

1. selecting and constructing a snail pen for snail production;

2. breeding and feeding of snails for snail production;

3. routine management practices for snail production;

4. prevention and control of pests and diseases for snail production;

5. harvesting, processing and marketing for snail production in Enugu State.

\subsection{Research Questions}

1. What are the entrepreneurial skills required by youths in selecting and constructing a snail pen for snail production in Enugu State?

2. What are the entrepreneurial skills required by youths in breeding and feeding of snails for snail production in Enugu State?

3. What are the entrepreneurial skills required by youths in routine management practices for snail production in Enugu State?

4. What are the entrepreneurial skills required by youths in prevention and control of pests and diseases for snail production in Enugu State? 
5. What are the entrepreneurial skills required by youths in harvesting, processing and marketing for snail production in Enugu State?

\section{Literature Review}

Relevant literatures in snail production were thematically discussed below.

\subsection{Snail Farming and Importance}

Snail rearing also known as Heliculture or Snail Production or Snail farming is recently practiced in different parts of Nigeria, Enugu state inclusive, though it is being overlooked by many youths [15]. It can be described as the act of domesticating and breeding edible land snails for the purpose of consumption or for onward sales. Snail production is an environment-friendly venture, because, unlike poultry or pigs, neither the snail nor its droppings smell offensively. Snails can be reared in the backyard and its manure improves the organic content of the soil. The prospects of snail farming over most other livestock includes low capital requirement, for its establishment and operation, less demand of professional knowledge, very high fecundity and low mortality, less labour requirement and availability of ready domestic and international markets among others $[15 ; 4 ; 3 ; 22]$. Snail production can be adequately harnessed for complementing protein meals engender wealth creation and achieving self-sufficiency as it provides self-employment to the people especially in present economic hardship in Enugu state [3; 22; 23].

Nutritionally, snail meat, also called "Congo meat", is higher in protein $(31-50 \%)$ compared to other livestock meats. It is also rich in iron, calcium, potassium, magnesium and contains low fat $[23 ; 14 ; 7 ; 8]$. Ref [2] noted that snail meats contain most of all amino acids required by humans. The formulation from slimes of snails are medicinal and used for treating cough, anaemia, burns, measles, small pox, abscesses, hypertension, poor sight, ulcer, asthma and protecting the liver among others. The shells are mostly used as ornamentals and in some cases utilized for livestock feed formulation $[23 ; 7 ; 12$; 15]. Therefore, the benefits of rearing snails cannot be underscored. Notably, the scarcity and high cost of meat for human consumption has given rise to the drive for intensive rearing of some non-conventional livestock such as snails which were usually hunted from the wild [18]. Snail rearing is suitable in the humid tropical rain forest zone like Enugu state, Nigeria, without artificial means of climate control. This zone offers a relatively constant temperature, high relative humidity and a fairly constant day/night rhythm throughout the year for snail rearing [23; 4].

\subsection{Challenges of Commercial Snail Farming}

Despite the prospects and awakened interests of individuals in snail production in different parts of Nigeria, one of the major reasons for failures recorded in snail production enterprise is incompetency of breeders [20]. This opinion is supported by Ref [16], who identified that lack of technical-know-how is a factor militating against snail farming. This implies that some farmers lack the required skills and knowledge in building a profitable snail farm enterprise. It is equally one of the reasons why most youths do not engage in this form of livestock farming. In a study, Ref [16] found that commercial snail farming in some parts of Nigeria was constrained by lack of finance and access to credit facilities. Ref [23] rightly noted that short repayable period of credit facilities and inability to access credit by farmers due to high collaterals have been part of the problems that have affected commercial farming in some areas of Nigeria. Another constraint to commercial snail production is unfavourable environmental conditions [16]. According to Ref [28], the environmental factors include the climatic factors, high rate of theft, incidence of wild fire, and insecurity of the area. Unfavourable climate conditions and climate change pose a serious problem to snail population and farming in West African Region. Climatic influence and its effects on snails have an associative effect on temperature, humidity, wind/air movement, light intensity and water logged soil [16]. Pests and diseases infestation is another challenge to snail farming. One of the greatest enemies of snails is insect-pest; some of these insects are also vectors of diseases. Apart from diseases, Ref [29] explained that cannibalism is a great problem in snail farming. This is observed in older snails feeding on the eggs yet to hatch and newly hatchlings as a source of nutrients, especially calcium and water to avoid dehydration and for their survival

\subsection{Entrepreneurial Skills in Snail Production}

A profitable snail production requires possession of certain entrepreneurial skills by individuals. In a study, Ref [10] found that vocational and technical skills required by graduate youths of River state-Nigeria in snail production include creating a conducive environment for snails, removing breeding stock from pen after laying eggs, supplying water to snails, keeping records of observable deficiencies, supply feeds, preventing predators and insects, selecting good stock for breeding and hatchability skills in pen construction. Aside these vocational skills, preventing and controlling pests and diseases in snail farm is important as disease infestation is one of its barriers [23]. A study conducted by [21] in Ebonyi state, Nigeria, revealed that entrepreneurial or occupational skills required by graduates of secondary schools for snail production were identified under areas 
such as skills in housing, feeding, routine management and disease control for breeding and rearing of snails. Ref [27] examined skills required by NCE graduates of Agricultural education in South Eastern Nigeria for processing and marketing of snail for employment on graduation. In a broad sense, Ref [10] identified entrepreneurial skills in snail production under two areas such as vocational and technical, and business management skills. However, researchers based on practical experiences and review of related literature are of the opinion that to be successful in snail production enterprise, potential entrepreneurs require basically entrepreneurial skills in ten specific areas which include selection of suitable site, construction of snail pen (housing), selection of good foundation stock for breeding, breeding of snails, feeding of snails, routine management practices, pest and disease prevention and control techniques, harvesting, processing and marketing of snails.

\subsubsection{Selecting of Site/Breeding Stock and Housing}

In selecting a good site for snail farming, adequately shaded dry land should be considered [15]. Snails could be reared in cages, concrete pens, tanks and tarpaulin. After selecting a suitable site, the farmer has to select a good breeding stock. Breeding stocks are animals that have desirable potential and quality needed for production of quality young ones [21]. Certain qualities worthy of consideration in selecting good species of stock for breeding include; hatchability, fecundity establishment, growth rate, good strong shell, snails that fill heir shell, large snails, type of snail $[16 ; 8]$, and health status of snails. Selecting good species of snails for breeding is essential because the success of snail rearing depends on quality of the foundation stock [8]. The Giant African Land Snail (GALS) is the mostly reared species in Nigeria and the largest species of land Snail. It is normally found in forest Areas, under natural environment in many part of Nigeria [21]. The choice of housing depends on the scale of production, available and management system (intensive, semi-intensive an extensive) to be adopted. Generally, when constructing a snail pen, it is advisable that the floor should not be cemented but ordinary soil covered with leaves to create a suitable moist environment for snails to thrive. Currently, some snail breeders use concrete floors while maintaining a certain level of soil depth; this has been one of the innovative strategies to control insects. Dwarf wall with bricks of about $1.5 \mathrm{~m}$ high with high wire gauge at the top of the wall can also be used to construct snail pen. Also, an ant-proof gutter should be built around the snail pen for pest control [7].

\subsubsection{Breeding of Snails}

Before breeding, the soil in snail pen should be treated with suitable insecticides to kill insect-pests of snails. Also, old engine oil, water or any suitable chemical should be poured into the ant-proof gutter surrounding the snail pen to prevent insect attack. Similarly, earth worms should be encouraged to grow in the soil where snails are to be reared because it keeps the pen clean by feeding on debris. This could be accomplished by ensuring the soil is moist and also the presence of leaves and other organic matters snails can feed on $[7 ; 15 ; 21]$. Snails selected for breeding are carefully handled and transported in baskets to avoid hurting them. Pen environment must be kept clean and disinfected before arrival of snails. The snail pen floor must be moistened when dry, feed stuffs are also placed strategically; then, snails are laid into the pen at different locations in cool evening not in the day when the sun is hot. Farmers should endeavour to avoid pen overcrowding; hence the right number of snails per unit area of the pen should be stocked, not more than 1-7 mature snails per square meter for breeding. After introducing the snails into the pen, regular inspections and observations should be made the following morning to fish out dead snails and those that crawled out to replace them. In roughly two weeks, the snails should be accustomed to their new environment $[8,24]$ and under adequate management and feeding they will reproduce. Eggs of snails are usually hatched 2-3 weeks after egg production. At about 6-8 weeks, hatchlings are separated into the hatchling pen at rearing densities of about $100 / \mathrm{m}^{2}$ [24]. Then hatchlings are feed and managed till maturity or market weight.

\subsubsection{Feeding of Snails}

Feeding of snails is relatively cheap and affordable. Snails vegetarians and mostly consume vegetables, fruits and fungi. They can be fed with pawpaw fruits, potato leaves, okra, water leaf, palm fruits, tomatoes, maize chaff, palm kernel cake, fish meal, cassava tuber, cocoyam, plantain, bananas, guava and other fruits [22; 15]. Ref [21] in a study found that some occupational skills required by secondary school graduates on feeding snails include identifying local feed stuff used for feeding snails, supplying quality, clean, fresh and adequate feeds, providing vegetables and fruits, adding water during hatching, identifying feedstuffs consumed rapidly by snails. The authors [21] also found that occupational skills required by secondary school graduates on routine management practices in snail production include; cleaning the pen more than 4-6 times a week which is dependent on substrate used and number of snail to use, cleaning the feeding trough regularly, providing water all the time, sterilizing the breeding pen, selecting good stock for breeding, placing water and feed for breeding snail, removing breeding stock from the pen after laying eggs, ensuring wet environment in the pen and ensuring good hatchability, regular observations of snails, keeping weight records for sales, recording any deficiency observed in the pen, feeding of snails in the evening among other. 


\subsubsection{Pest and Disease Control in Snail Production}

Pests of snails include termites, soldier ants, frogs, toads, rats, snail eating birds, lizards, and larvae of some beetles. The most dangerous pests of snails are insects. Therefore, insect attack is usually prevented by constructing ant-proof gutters round the snailry; this gutter is filled with old engine oil or any other liquid substance which could prevent insects from crawling into the snail pen. More so, soil in the snail pen can be treated against insects and soil-borne pathogens. A careful use of any suitable pesticides not toxic to snails is also advisable. Adopting good sanitary measures can as well help to prevent pests and predators of snails $[10 ; 9 ; 8 ; 15]$.

Diseases of land snails are commonly caused by parasites such as Alluaudihella flavicornis, Angiostoma aspersae (nematodes), Phasmarhabditis hermaphrodita and Fasciola hepatica, while fungal disease (pink egg disease) is caused by the fungus, Fusarium spp. Bacterial disease is caused by Pseudomonas spp. and these species infect the intestines of snails [9]. Cannibalisms, overcrowding and feed deficiency diseases also affect the health of snails $[5 ; 11 ; 8]$. Ref [21] found that secondary school graduates require the following skills in preventing and controlling diseases of snails; identifying and selecting healthy stock for mating, disinfecting the ground floor against fungi, bacteria, virus, among others before introducing stock., keeping the snail pen clean regularly, providing clean, water, feed; and others feed additives, preventing contact with other foreign body to avoid contamination and culling any dictated sick snail from the pen. Ref [9] noted that practicing good pen hygiene can help prevent the spread of disease in snail production. In addition, other important entrepreneurial skills to be reckoned with in snail production beside controlling and preventing pests and disease are harvesting, processing and marketing skills.

\subsubsection{Harvesting, Processing and Marketing of Snails}

Snails that are properly managed will mature within 12-24 months at $200 \mathrm{gm}$ (when the lip edge of the snail hardens), depending on the variety. Harvesting of snails is usually done through hand-picking, mainly at night or when it is dew [8]. Snails are locally harvested into a basket or any other suitable container in Nigeria. After harvest, snails are processed before they are sent to the market. Ref [27] found that skills required by NCE graduates of Agricultural education in South Eastern Nigeria for processing of snail include transferring harvested snails to cage, breaking snail shells with hard objects, separating the shell from the snail, boiling enough quantity of water with which to wash the snail inside a lid bucket, removing the slime with substances such as garri, alum, fermented cassava or lime and packaging. In marketing of snails, snails are graded, sorted, recorded and packed in net box or suitable containers to sell. The prices of snails can be determined by weight or based on negotiation between the seller and the buyer; however, market conditions and seasons affect prices of snails. Snails can be sold in local markets, hotels, restaurants and at farm gates. They can be sold with shells, processed as fresh frozen, bottled or canned. It is important to note that the market for snails should be identified before and during production through adverts [27, 15]. Ref [10] observed that graduates youths also require marketing, accounting and book-keeping, leadership, communication, decision making, strategic planning, and time management, creative and innovative, networking and problem-solving skills in snail production for entrepreneurship development. These set of skills were viewed by [10] as business management skills in snail production.

\section{Methodology}

The study was conducted in Enugu State, Nigeria, which geographically lies approximately on latitude $6.5364^{\circ} \mathrm{N}$ and longitude $7.4356^{\circ} \mathrm{E}$ in the South-East geopolitical zone of Nigeria. A descriptive survey research design was adopted for the study. Researchers used a multistage sampling technique in the selection of respondents (snail farmers) for the study. Enugu State has seventeen Local Government Areas and six agricultural zones, thus two Local Government Areas from each of the six (6) agricultural zones (Agwu, Agbani, Enugu, Nsukka, Enugu Ezike \& Udi) were randomly selected, resulting to a total of twelve (12) Local Government Areas selected for the Study. In the second stage, two (2) autonomous communities were randomly sampled from each LGA, to give a total of twenty four (24) autonomous communities. In the third stage, three (3) villages were randomly sampled from the twenty four (24) autonomous communities to give a total of seventy two (72) villages. Lastly, three (3) youths into snail farming were purposively selected from each of the villages with the aid of accidental sampling technique. This culminated to the final selection of two hundred and sixteen (216) youths that were used as the sample size for the study. Data were voluntarily collected from respondents through the use of an adapted structured questionnaire entitled "Snail Production Skill Questionnaire" (SPSQ). The SPSQ was validated by 3 experts, one in the field of Agricultural Education and two in the field of Animal Science. The questionnaire (SPSQ) was structured on a 4-point scale with corresponding values such as 4, 3, 2 and 1 respectively (Highly Required, Moderately Required, Lowly Required and Not Required). The instrument was pilot tested with 15 youths who are into farming in Abia State-Nigeria and the reliability index was .89 using Cronbach's Alpha Test. Data collected for the study were analyzed using descriptive statistics such as mean and standard deviation. Mean scores $\geq 2.5$, an average on 
4-point scale, were described as "Required or Agreed" while mean scores $<2.5$ average on 4-point scale were described as "Not Required or Disagreed". Researchers organized and analyzed primary data descriptively with the aid of Excel and SPSS -version 22.

\section{Results}

The results of the descriptive and inferential analyses were presented in Tables as follows.

\section{Research Question 1}

What are the entrepreneurial skills required by youths in selecting and constructing a snail pen for snail production in Enugu State?

Data for answering research question 1 are presented in Table 1 below.

Data presented in Table 1 reveal that the mean ratings of respondents for all the 15 items range from 2.95 to 3.41 which are above 2.50 on 4-point scale. This implies that respondents agreed that entrepreneurial skills required by youths in selecting and constructing a snail pen for snail production in Enugu State include identifying and selecting adequately shaded and well drained land for the construction of snail pen through careful observations and soil analysis, sites that are protected from wind which will prevent snails from drying out, sandy-loamy soil for snailry, sites near to the source of water, feedstuffs and market for snails and the type of snail pen to be used for snail production such as tank, cage, concrete pen, house, tarpaulin, etc, sourcing materials for constructing the type of snail pen selected (woods, nylon mesh, car tires, oil drums, wire mesh, nails, tarpaulin, tank, blocks, cement, soil, etc), clearing of site for the construction, mapping out the dimension of the snail pen using measuring tape, among others in Table 1. More so, standard deviations for the 15 items in Table 1 range from .482 to .787; this shows that the responses of respondents were close to the mean and to one another in degrees of responses.

Table 1. Mean ratings of respondents on the entrepreneurial skills required by youths in selecting and constructing a snail pen for snail production in Enugu State $(\mathrm{n}=216)$

\begin{tabular}{|c|c|c|c|c|}
\hline $\mathbf{S} / \mathbf{N}$ & Item Statement & $\overline{\mathbf{X}}$ & $S$ & Decision \\
\hline 1 & $\begin{array}{l}\text { Identifying and selecting adequately shaded and well drained land for the construction of snail pen } \\
\text { through careful observations and soil analysis }\end{array}$ & 3.29 & .787 & $\mathrm{R}$ \\
\hline 2 & $\begin{array}{l}\text { Identifying and selecting sites that are protected from wind which will prevent snails from drying } \\
\text { out }\end{array}$ & 3.27 & .592 & $\mathrm{R}$ \\
\hline 3 & Identifying and selecting site free from predators and poachers & 3.19 & .785 & $\mathrm{R}$ \\
\hline 4 & Identifying and selecting sandy-loamy soil for snailry & 3.41 & .700 & $\mathrm{R}$ \\
\hline 5 & Identifying and selecting sites near to the source of water, feedstuffs and market for snails & 3.26 & .777 & $\mathrm{R}$ \\
\hline 6 & $\begin{array}{l}\text { Identifying and selecting the type of snail pen to be used for snail production such as tank, cage, } \\
\text { concrete pen, house, tarpaulin, etc }\end{array}$ & 3.13 & .727 & $\mathrm{R}$ \\
\hline 7 & $\begin{array}{l}\text { Sourcing materials for constructing the type of snail pen selected (woods, nylon mesh, car tires, oil } \\
\text { drums, wire mesh, nails, tarpaulin, tank, blocks, cement, soil, etc) }\end{array}$ & 3.33 & .744 & $\mathrm{R}$ \\
\hline 8 & Clearing of site for the construction of snail pen & 3.30 & .735 & $\mathrm{R}$ \\
\hline 9 & Mapping out the dimension of the snail pen using measuring tape & 3.13 & .779 & $\mathrm{R}$ \\
\hline 10 & Planting shady plants like plantain and banana around the mapped out area of the snail pen & 3.34 & .679 & $\mathrm{R}$ \\
\hline 11 & $\begin{array}{l}\text { Constructing the type of snail pen identified and selected for snail production by self or through } \\
\text { hired labour and ensuring it is screened with wire mesh or any other suitable material against } \\
\text { predators (breeding pen, hatchling pen and adult pen) }\end{array}$ & 3.34 & .687 & $\mathrm{R}$ \\
\hline 12 & $\begin{array}{l}\text { Ensuring snail pen is erected at east-west direction to reduce the effects of sunlight from drying the } \\
\text { snails and environment. }\end{array}$ & 3.06 & .544 & $\mathrm{R}$ \\
\hline 13 & Using coarse gravel of about $20 \mathrm{~mm}$ depth on the floor of the snail pen & 2.95 & .705 & $\mathrm{R}$ \\
\hline 14 & Adding humus soil on top of the gravel to a certain depth & 3.11 & .482 & $\mathrm{R}$ \\
\hline 15 & $\begin{array}{l}\text { Constructing ant-proof gutter around the snail pen which will be filled with old engine oil or any } \\
\text { ant trap or repellent oil }\end{array}$ & 3.01 & .524 & $\mathrm{R}$ \\
\hline
\end{tabular}

$\overline{\mathbf{x}}=$ mean, $\mathbf{S}=$ Standard deviation, $\mathbf{R}=$ Required, $\mathbf{N R}=$ Not required, $\mathbf{n}=$ number of respondents 


\section{Research Questions 2}

What are the entrepreneurial skills required by youths in breeding and feeding of snails for snail production in Enugu State?

Data for answering research question 2 are presented in Table 2 below.

Data presented in Table 2 show that mean ratings of respondents for the 19 items range from 2.61 to 3.46 which are above 2.50 on 4-point scale. This indicates that respondents agreed that information represented in Table 2 are entrepreneurial skills required youths in breeding and feeding of snails for snail production in Enugu State. These include identifying and selecting good local species of edible land snail for breeding, good foundations stock of the selected species for breeding based on fecundity, feed conversion ratio, growth rate, hatchability and establishment, and disinfecting the snail pen two weeks before breeding, ensuring the soil environment is moistened and good for snails before introducing the breeding stock, making sure all feeding and drinking troughs are clean and disinfected and put into the breeding pen, introducing feedstuff into breeding pen before arrival of the breeding stock (Paw paw, palm fruit, potato leaves, vegetables, plantain leaves, melon peels, etc), carefully introducing the foundation stock into the breeding pen at cool evening and at strategic places in the snail pen, and ensuring good stocking densities for breeding (7-10 mature snails $/ \mathrm{m}^{2}$ ), among others in Table 2. Also, standard deviations for all the items range from .347 to 1.042; which implies that the responses of respondents were close to the mean and to one another in degrees of responses.

Table 2. Mean ratings of respondents on the entrepreneurial skills required by youths in breeding and feeding of snails for snail production in Enugu State $(\mathrm{n}=216)$

\begin{tabular}{|c|c|c|c|c|}
\hline $\mathbf{S} / \mathbf{N}$ & Item Statement & $\overline{\mathbf{X}}$ & $S$ & Decision \\
\hline 1 & $\begin{array}{l}\text { Identifying and selecting good local species of edible land snail for breeding (Example, } \\
\text { Achatina spp) }\end{array}$ & 3.41 & .700 & $\mathrm{R}$ \\
\hline 2 & $\begin{array}{l}\text { Identifying and selecting good foundations stock of the selected species for breeding } \\
\text { based on fecundity, feed conversion ratio, growth rate, hatchability and establishment }\end{array}$ & 3.46 & 1.042 & $\mathrm{R}$ \\
\hline 3 & Disinfecting the snail pen two weeks before breeding & 3.01 & .711 & $\mathrm{R}$ \\
\hline 4 & $\begin{array}{l}\text { Ensuring the soil environment is moistened and good for snails before introducing the } \\
\text { breeding stock }\end{array}$ & 3.33 & .744 & $\mathrm{R}$ \\
\hline 5 & $\begin{array}{l}\text { Ensuring all feeding and drinking troughs are clean and disinfected and put into the } \\
\text { breeding pen }\end{array}$ & 2.82 & .770 & $\mathrm{R}$ \\
\hline 6 & $\begin{array}{l}\text { Introducing feedstuff into breeding pen before arrival of the breeding stock (Paw paw, } \\
\text { palm fruit, potato leaves, vegetables, plantain leaves, melon peels, etc) }\end{array}$ & 3.09 & .702 & $\mathrm{R}$ \\
\hline 7 & $\begin{array}{l}\text { Carefully introducing the foundation stock into the breeding pen at cool evening and at } \\
\text { strategic places in the snail pen }\end{array}$ & 2.88 & .880 & $\mathrm{R}$ \\
\hline 8 & Ensuring good stocking densities for breeding $\left(7-10\right.$ mature snails $\left./ \mathrm{m}^{2}\right)$ & 3.37 & .782 & $\mathrm{R}$ \\
\hline 9 & $\begin{array}{l}\text { Ensuring the ant-proof gutter is filled with old engine oil or any other suitable oil to wall } \\
\text { off insects especially soldier ants }\end{array}$ & 2.61 & .996 & $\mathrm{R}$ \\
\hline 10 & $\begin{array}{l}\text { Inspecting the breeding stock the next morning to replace any mortality and to put back } \\
\text { anyone that crawled out }\end{array}$ & 3.34 & 625 & $\mathrm{R}$ \\
\hline 11 & $\begin{array}{l}\text { Feeding the breeding snails generously in the evening and keeping small quantity of feed } \\
\text { for night. }\end{array}$ & 3.34 & .798 & $\mathrm{R}$ \\
\hline 13 & Observing how the snails adapt to their new environment & 3.26 & .823 & $\mathrm{R}$ \\
\hline 14 & Keeping records of observations and mortality & 2.92 & .812 & $\mathrm{R}$ \\
\hline 15 & Watching out for egg production (especially for hermaphrodites, eg., Achatina spp) & 3.11 & .347 & $\mathrm{R}$ \\
\hline 16 & Watching out for hatching of new snails 2-3 weeks after egg production & 3.24 & .643 & $\mathrm{R}$ \\
\hline \multirow[t]{2}{*}{17} & $\begin{array}{l}\text { Separating the young snails } 6-8 \text { weeks after hatching into a well cleaned, disinfected and } \\
\text { moist hatching pen with feedstuffs }\end{array}$ & 3.12 & .548 & $\mathrm{R}$ \\
\hline & Maintaining rearing densities for hatchlings $\left(100 / \mathrm{m}^{2}\right)$ & 3.22 & .936 & $\mathrm{R}$ \\
\hline 18 & Ensuring feeds and water are provided generously for hatchlings & 3.14 & .841 & $\mathrm{R}$ \\
\hline 19 & $\begin{array}{l}\text { Inspecting the hatchlings and keeping records of weight and other observations till } \\
\text { maturity }\end{array}$ & 3.09 & .636 & $\mathrm{R}$ \\
\hline
\end{tabular}

$\overline{\mathbf{x}}=$ mean, $\mathbf{S}=$ Standard deviation, $\mathbf{R}=$ Required, $\mathbf{N R}=$ Not required, $\mathbf{n}=$ number of respondents 


\section{Research Question 3}

What are the entrepreneurial skills required by youths in routine management practices for snail production in Enugu State?

Data for answering research question 3 are presented in Table 3 below.

Data in Table 3 indicate that the mean ratings of respondents for all the 14 items range from 2.71 to 3.64 which are above 2.50 on 4-point scale. This implies that respondents agreed that entrepreneurial skills required by youths in routine management practices for snail production in Enugu State include identifying and selecting healthy stock for subsequent breeding, ensuring the snail pen is moist always especially during drought to prevent the snails from drying out, providing clean and fresh water and feed daily at cool evening for snails, inspecting the snails regularly, isolating any observed sick snails from the pen, preparing feeds for snails and others in Table 3More so, standard deviations for all the items range from .630 to 1.239; this means that the responses of respondents were close to the mean and to one another in degrees of responses.

\section{Research Question 4}

What are the entrepreneurial skills required by youths in prevention and control of pests and diseases for snail production in Enugu State?

Data for answering research question 4 are presented in Table 4 below.

Table 3. Mean ratings of respondents on the entrepreneurial skills required by youths in routine management practices for snail production in Enugu State $(\mathrm{n}=216)$

\begin{tabular}{clccc}
\hline S/N & \multicolumn{1}{c}{ Item Statement } & $\overline{\mathbf{X}}$ & \multicolumn{1}{c}{$\boldsymbol{S}$} & Decision \\
\hline 1 & Identifying and selecting healthy stock for subsequent breeding & 3.64 & .630 & $\mathrm{R}$ \\
2 & Ensuring the pen environment is moist always especially during drought to prevent the snails & 3.13 & 1.081 & $\mathrm{R}$ \\
3 & from drying out & 2.81 & .980 & $\mathrm{R}$ \\
4 & Providing clean and fresh water and feed daily at cool evening for snails & 3.04 & 1.021 & $\mathrm{R}$ \\
5 & Inspecting the snails regularly & 3.11 & 1.132 & $\mathrm{R}$ \\
6 & Isolating any observed sick snails from the pen & 2.65 & 1.239 & $\mathrm{R}$ \\
7 & Ensuring the pen floor and surroundings are clean regularly. & 3.30 & 1.086 & $\mathrm{R}$ \\
8 & Washing of feeding and drinking trough regularly & 3.13 & 1.082 & $\mathrm{R}$ \\
9 & Careful handling and weighing of snails & 3.13 & 1.018 & $\mathrm{R}$ \\
10 & Separating large size snails from small size snails & 2.61 & .665 & $\mathrm{R}$ \\
11 & Identifying snails with good market weight and size & 3.12 & 1.103 & $\mathrm{R}$ \\
12 & Preparing feeds for snails & 3.11 & .965 & $\mathrm{R}$ \\
13 & Keeping records of mortality and escape & 2.71 & 1.051 & $\mathrm{R}$ \\
14 & Keeping financial records & 3.13 & .756 & $\mathrm{R}$ \\
\hline
\end{tabular}

$\overline{\mathbf{x}}=$ mean, $\mathbf{S}=$ Standard deviation, $\mathbf{R}=$ Required, $\mathbf{N R}=$ Not required, $\mathbf{n}=$ number of respondents

Table 4. Mean ratings of respondents on the entrepreneurial skills required by youths in prevention and control of pests and diseases for snail production in Enugu State $((\mathrm{n}=216)$

\begin{tabular}{clccc}
\hline $\mathbf{S} / \mathbf{N}$ & & \multicolumn{1}{c}{ Item Statement } & \multicolumn{1}{c}{$S$} & \multicolumn{1}{c}{ Decision } \\
\hline 1 & Keeping the pen floor and environment clean regularly & 3.01 & .555 & $\mathrm{R}$ \\
2 & $\begin{array}{l}\text { Disinfecting the pen environment to kill parasites such as fungi, bacteria, virus, among others } \\
\text { before arrival of breeding stock }\end{array}$ & 3.58 & .658 & $\mathrm{R}$ \\
3 & Treating the soil with suitable pesticides & 3.70 & .578 & $\mathrm{R}$ \\
4 & Regular washing of the drinking and feeding trough & 2.67 & .524 & $\mathrm{R}$ \\
5 & Using suitable insecticides carefully to wall off insects & 3.37 & .579 & $\mathrm{R}$ \\
6 & Using the ant-proof gutter to restrict insects from entering the snailry & 3.19 & .645 & $\mathrm{R}$ \\
7 & Identifying and using disease free stock for breeding & 2.98 & .349 & $\mathrm{R}$ \\
8 & Providing clean and fresh feed and water & 3.00 & .649 & .513 \\
9 & Ensuring snails do not come in contact with infected materials & 2.81 & $\mathrm{R}$ \\
10 & Adequate feeding of snails to prevent feed deficiency & 3.41 & .938 & $\mathrm{R}$ \\
11 & Ensuring good stocking rate to avoid overcrowding and cannibalism & 3.19 & .440 \\
\hline
\end{tabular}

$\overline{\mathbf{x}}=$ mean, $\mathbf{S}=$ Standard deviation, $\mathbf{R}=$ Required, $\mathbf{N R}=$ Not required, $\mathbf{n}=$ number of respondents 
Data in Table 4 show that mean ratings of respondents for all the 6 items range from 2.67 to 3.70 which are above 2.50 on 4-point scale. This shows that respondents agreed that the entrepreneurial skills required by youths in preventing and controlling pests and diseases of snails include keeping the pen floor and environment clean regularly, disinfecting the pen environment to kill parasites such as fungi, bacteria, virus, among others before arrival of breeding stock, treating the soil with suitable pesticides, regular washing of the drinking and feeding trough, using suitable insecticides carefully to wall off insects, identifying and using disease free stock for breeding, providing clean and fresh feed and water to the snails, ensuring snails do not come in contact with infected materials, adequate feeding of snails to prevent feed deficiency and ensuring good stocking rate to avoid overcrowding and cannibalism. Also, standard deviations for all items range from .349 to .658 ; this reveals that the responses of respondents were close to the mean and to one another in degrees of responses.

\section{Research Question 5}

What are the entrepreneurial skills required by youths in harvesting, processing and marketing for snail production in Enugu State?

Data for answering research question 5 are presented in Table 5 below.
Data in Table 5 reveal that the mean ratings of respondents for all the 13 items range from 2.69 to 3.41 which are above 2.50 on 4-point scale. This indicates that respondents perceived that entrepreneurial skills required by youths in harvesting, processing and marketing of snails include Identifying potential markets (supermarkets, hotels, restaurants, catering institutions and individuals along the road) before, during and after production, identifying snails with good market weight and size, handpicking snails with good market weight and size at night or cool evening, handling and transporting handpicked mature snails by using a basket, net, plastic or wooden crates (or nay other suitable container), careful cleaning of snails with dry and clean rags or foam, sorting of snails based on sizes and state especially snails that will be sold with shells, breaking the shells of snails carefully with hard objects, especially snails that will not be sold with shells at the market, separating the broken shells from the meat for slime removal, removing the intestine of the snails manually (with finger tip), removing the slime of snails locally using substances such as salt, garri, lime, lemon and alum, rinsing off the slime-extracting substances (salt, garri, lime, lemon and alum) from the meat and others in Table 5. In addition, standard deviations of responses for all the items range from .089 to 1.100 ; this implies that the responses of respondents were close to the mean and to one another in degrees of responses.

Table 5. Mean ratings of respondents on harvesting, processing and marketing for snail production in Enugu State $(n=216)$

\begin{tabular}{|c|c|c|c|c|}
\hline $\mathbf{S} / \mathbf{N}$ & Item Statement & $\overline{\mathbf{x}}$ & $S$ & Decision \\
\hline 1 & $\begin{array}{l}\text { Identifying potential markets (supermarkets, hotels, restaurants, catering institutions and } \\
\text { individuals along the road) before, during and after production }\end{array}$ & 3.45 & .958 & $\mathrm{R}$ \\
\hline 2 & Identifying snails with good market weight and size & 3.12 & 633 & $\mathrm{R}$ \\
\hline 3 & Handpicking snails with good market weight and size at night or cool evening & 3.05 & .557 & $\mathrm{R}$ \\
\hline 4 & $\begin{array}{l}\text { Handling and transporting handpicked mature snails using a basket, net, plastic or wooden crates } \\
\text { (or nay other suitable container) to the place where it will be processed }\end{array}$ & 2.98 & .089 & $\mathrm{R}$ \\
\hline 5 & Careful cleaning of snails with dry and clean rags or foam & 3.41 & .183 & $\mathrm{R}$ \\
\hline 6 & Sorting of snails based on sizes and state especially snails that will be sold with shells & 2.86 & .632 & \\
\hline 7 & $\begin{array}{l}\text { Breaking the snail shells carefully with hard objects especially snails that will not be sold with } \\
\text { shells at the market }\end{array}$ & 2.98 & .854 & $\mathrm{R}$ \\
\hline 8 & Separating the broken shells from the meat for slime removal & 2.69 & .955 & $\mathrm{R}$ \\
\hline 9 & Removing the intestine of the snails manually (with finger tip) & 3.11 & .849 & $\mathrm{R}$ \\
\hline 10 & Removing snail slime locally using substances such as salt, garri, lime, lemon and alum & 3.32 & .239 & $\mathrm{R}$ \\
\hline \multirow[t]{2}{*}{11} & Rinsing off the slime-extracting substances (salt, garri, lime, lemon and alum) from the meat & 3.29 & .092 & $\mathrm{R}$ \\
\hline & Storing of snail shells for supply to industries & & & \\
\hline 12 & Packaging of snails into bags, net containers, baskets, etc for market supply & 3.19 & 1.100 & $\mathrm{R}$ \\
\hline 13 & $\begin{array}{l}\text { Transporting and supplying packaged snails to target customers (supermarkets, hotels, } \\
\text { restaurants, catering institutions and individuals along the road) }\end{array}$ & 3.20 & .683 & $\mathrm{R}$ \\
\hline
\end{tabular}

$\overline{\mathbf{x}}=$ mean, $\mathbf{S}=$ Standard deviation, $\mathbf{R}=$ Required, $\mathbf{N R}=$ Not required, $\mathbf{n}=$ number of respondents 


\subsection{Discussion of Findings}

The findings of the study on research question 1 show that there are 15 entrepreneurial skills in selecting and constructing a snail pen for snail production in Enugu State. These entrepreneurial skills include identifying and selecting adequately shaded well drained land for the construction of snail pen through careful observations and soil analysis, identifying and selecting sites that are protected from wind which will prevent snails from drying out, identifying and selecting site free from predators and poachers, identifying and selecting sandy-loamy soil for snailry, identifying and selecting sites near to the source of water, feedstuffs and market for snails, identifying and selecting the type of snail pen to be used for snail production such as tank, cage, concrete pen, house, tarpaulin, etc, Sourcing materials for constructing the type of snail pen selected (woods, nylon mesh, car tires, oil drums, wire mesh, nails, tarpaulin, tank, blocks, cement, soil, etc), clearing of site for the construction of snail pen, mapping out the dimension of the snail pen using measuring tape, planting shady plants like plantain and banana around the mapped out area of the snail pen, constructing the type of snail pen identified and selected for snail production by self or through hired labour and ensuring it is screened with wire mesh or any other suitable material against predators (breeding pen, hatchling pen and adult pen), ensuring snail pen is erected at east-west direction to reduce the effects of sunlight from drying the snails and environment, using coarse gravel of about $20 \mathrm{~mm}$ depth on the floor of the snail pen, adding humus soil on top of the gravel to a certain depth and constructing ant-proof gutter around the snail pen which will be filled with old engine oil or any ant trap or repellent oil. Some of the findings of this study are in line with Ref [21], who acknowledged that snails can be reared in cages, concrete pens, tanks and tarpaulin as well as emphasized the need to provide a moist environment for snails. The authors' views are also in agreement with [15] and [7] who in addition are of the opinion that adequately shaded dry land should be used for snail farming. Also, when constructing a snail pen, the floor should not be cemented but ordinary soil covered with leaves to create a suitable moist environment for snails to thrive $[7 ; 15 ; 21]$.

The results of the study on research question 2 reveal that there are 19 entrepreneurial skills in breeding and feeding of snails for snail production in Enugu State. These include identifying and selecting good local species of edible land snail for breeding (Example, Achatina spp), identifying and selecting good foundations stock of the selected species for breeding based on fecundity, feed conversion ratio, growth rate, hatchability and establishment, disinfecting the snail pen two weeks before breeding, ensuring the soil environment is moistened and good for snails before introducing the breeding stock, ensuring all feeding and drinking troughs are clean and disinfected and put into the breeding pen, introducing feedstuff into breeding pen before arrival of the breeding stock (Paw paw, palm fruit, potato leaves, vegetables, plantain leaves, melon peels, etc), carefully introducing the foundation stock into the breeding pen at cool evening at strategic places in the snail pen, ensuring good stocking densities for breeding (7-10 mature snails $/ \mathrm{m}^{2}$ ), ensuring the ant-proof gutter is filled with old engine oil or any other suitable oil to wall off insects especially soldier ants, inspecting the breeding stock the next morning to replace any mortality and to put back anyone that crawled out, feeding the breeding snails generously in the evening and keeping small quantity of feed for night, observing how the snails adapt to their new environment, keeping records of observations and mortality, watching out for egg production (especially for hermaphrodites, eg., Achatina spp), watching out for hatching of new snails 2-3 weeks after egg production, separating the young snails 6-8 weeks after hatching into a well cleaned, disinfected and moist hatching pen with feedstuffs, maintaining rearing densities for hatchlings $\left(100 / \mathrm{m}^{2}\right)$, ensuring feeds and water are provided generously for hatchlings and inspecting the hatchlings and keeping records of weight and other observations till maturity. Some of these findings are in agreement with [8], who noted that certain qualities such as fecundity, hatchability, establishment, growth rate, good strong shell, snails that fill heir shell, large snails and type of snail qualities are worthy of consideration in selecting good species of stock for breeding. Researchers are of the opinion that health status of snails is also a factor to consider. This is because the success of snail rearing depends on quality of the foundation stock [8]. Ref [21] found that selecting good stock for breeding is a skill in snail breeding operations. More, Ref [24] and also [8] agreed that during breeding, snails selected for breeding are carefully handled and transported in baskets to avoid hurting them, pen environment must be kept clean and disinfected before arrival of snails, pen floor must be moistened when dry, feed stuffs are also placed strategically; then, snails are laid into the pen at different locations in cool evening not in the day when the sun is hot. Ref [24] remarked that farmers should endeavour to avoid pen overcrowding; hence the right number of snails per unit area of the pen should be stocked, not more than 1-7 mature snails per square meter for breeding. Also, after introducing the snails into the pen, regular inspections and observations should be made the following morning to fish out dead snails and those that crawled out to replace them. In roughly two weeks, the snails should be accustomed to their new environment. Eggs of snails are usually hatched 2-3 weeks after egg production. At about 6-8 weeks, hatchlings are separated into the hatchling pen at rearing densities of about $100 / \mathrm{m}^{2}$. In line with some of the findings of this study, [22] and [15] recommended that snails can be fed with pawpaw fruits, potato leaves, palm 
fruits, tomatoes, maize chaff, palm kernel cake, fish meal, cassava tuber, cocoyam, plantain, bananas and guava. More so, Ref [21] found that providing clean and fresh feeds and water for snails, sterilizing breeding pen, ensuring wet environment in the pen among others are essential skills required by graduates of secondary schools These findings are also in line with Ref [10], who found that skills required by graduates youths of River state in snail production include creating a conducive environment for snails, removing breeding stock from pen after laying eggs, supplying water to snails, keeping records of observable deficiencies, supply feeds, preventing predators and insects, selecting good stock for breeding and hatchability skills in pen construction

The findings of the study on research question 3 indicate that there are 14 entrepreneurial skills required by youths in routine management practices for snail production in Enugu State. They include identifying and selecting healthy stock for subsequent breeding, ensuring the pen environment is moist always especially during drought to prevent the snails from drying out, providing clean and fresh water and feed daily at cool evening for snails, ensuring the snail pen gets adequate shades to prevent the effect of wind and sunlight, inspecting the snails regularly day and night, isolating any observed sick snails from the pen, ensuring the pen floor and surroundings are clean regularly, washing of feeding and drinking trough regularly, careful handling and weighing of snails, separating large size snails from small size snails, identifying snails with good market weight and size, preventing pests and diseases, preparing feeds for snails and keeping records of mortality, escape and finances. These findings are in agreement with the findings of [10], who found that supplying water to snails, keeping records of observable deficiencies, supply feeds and preventing predators and insects as essential skills in snail production. Also, Ref [21] identified that regular observations of snails, cleaning the pen more than 4-6 times a week which is dependent on substrate used and number of snail to use, cleaning the feeding trough regularly, providing water all the time, keeping weight records for sales, recording any deficiency observed in the pen and feeding of snails in the evening are occupational skills in snail production.

Results of the study on research question 4 show that there are 11 entrepreneurial skills required by youths in prevention and control of pests and diseases for snail production in Enugu State. These entrepreneurial skills among others include keeping the pen floor and environment clean regularly, Disinfecting the pen environment to kill parasites such as fungi, bacteria, virus, among others before arrival of breeding stock, washing of feedings and drinking troughs, ensuring snails do not come in contact with infected materials, providing fresh and clean water. In agreement with the findings of the study, Ref [21]) found that; identifying and selecting healthy stock for mating, disinfecting the ground floor against fungi, bacteria, virus, among others before introducing stock., keeping the snail pen clean regularly, providing clean, water, feed; and others feed additives, preventing contact with other foreign body to avoid contamination and culling any dictated sick snail from the pen are skills in preventing and controlling diseases of snails. Also, practicing good pen cleanliness can help prevent the spread of diseases in snail production [9].

The findings of the study on research question 5 reveal that 13 entrepreneurial skills required by youths in harvesting, processing and marketing of snails in Enugu state include; identifying potential markets (supermarkets, hotels, restaurants, catering institutions and individuals along the road) before, during and after production, identifying snails with good market weight and size, handpicking snails with good market weight and size at night or cool evening, handling and transporting handpicked mature snails using a basket, net, plastic or wooden crates (or nay other suitable container) to the place where it will be processed, careful cleaning of snails with dry and clean rags or foam, sorting of snails based on sizes and state especially snails that will be sold with shells, breaking the snail shells carefully with hard objects especially snails that will not be sold with shells at the market, separating the broken shells from the meat for slime removal, removing the intestine of the snails manually (with finger tip), removing snail slime locally using substances such as salt, garri, lime, lemon and alum, rinsing off the slime extracting substances (salt, garri, lime, lemon and alum) from the meat, storing of snail shells for supply to industries, packaging of snails into bags, net containers, baskets, etc for market supply and, transporting and supplying packaged snails to target customers (supermarkets, hotels, restaurants, catering institutions and individuals along the road). In agreement with one of the findings of this study, [8] stated that snails are harvested at night or when it's dew through handpicking. In addition, [27] found that skills for processing of snail include harvesting snails at maturity (when the lip edge of the snail hardens), transferring harvested snails to cage, breaking snail shells with hard objects, separating the shell from the snail, boiling enough quantity of water with which to wash the snail inside a lid bucket, removing the slime with substances such as garri, alum, fermented cassava or lime and packaging. Ref [21] and [15] are of the opinion that during marketing, snails are graded, sorted, recorded and packed in net box or suitable containers to sell. Also, prices of snails can be determined by weight or based on negotiation between the seller and the buyer; however, market conditions and seasons affect prices of snails. Snails can be sold in local markets, hotels, restaurants and at farm gates. They can be sold with shells, processed as fresh frozen, bottled or canned. It is important to note that the market for snails should be identified before and during production through adverts. 


\section{Conclusion and Recommendations}

\subsection{Conclusion}

To leverage snail production for wealth creation in Enugu state, youths require certain entrepreneurial skills in selecting and constructing a snail pen, breeding and feeding of snails, routine management practice, prevention and control of pests and diseases of snails, harvesting, processing and marketing of snails. This study therefore identified 15 entrepreneurial skills in selecting and constructing a snail pen, 19 entrepreneurial skills in breeding and feeding of snails, 14 entrepreneurial skills in routine management practices, 11 entrepreneurial skills in prevention and control of pests and diseases and 13 entrepreneurial skills in harvesting, processing and marketing of snails required by youths in snail production for wealth creation in Enugu state.

\subsection{Recommendations}

Based on the findings of this study the following recommendations were made:

- Agricultural extension agents in collaboration with community leaders in Enugu state should organize a workshop to educate jobless youths on the entrepreneurial skills in snail production identified by this study for wealth creation.

- Youths who are already into snail production should be exposed to the snail production entrepreneurial skills identified by this study for improved practices in Enugu state

- Youths who are already into any form of animal production should be exposed to the snail production entrepreneurial skills identified by this study through effective extension education for business expansion and wealth creation in Enugu state.

- Educational authorities and teachers of animal husbandry should utilize the snail production entrepreneurial skills identified by this study as a guide for training students in senior secondary schools

\section{REFERENCES}

[1] Ademosun, A. A. Omidiji, M.O. (1999) The Nutrient value of African giant land snail (Archachatina marginata) Journal of Animal Protection Research 8 (2): 876-877.

[2] Adeyeye, E.I. (2015). Waste yield, Proximate and mineral Composition of three different types of land snail found in Nigeria. International Journal of Food Science and Nutrition 42(2): 111-116.

[3] Agbogidi, O. M. \& Okonta, B. O. (2011). Reducing poverty through snail farming in Nigeria. Agriculture and Biology
Journal of
doi:10.5251/abjna.2011.2.1.169.172 North

[4] Akinbile, S.M. Teach yourself farming (snail rearing), 2nd edition. Ikire: Erodise ventures. (2000).

[5] Akinnusi O., (2014). Snail production and management. Tolukoya publishing company, Abeokuta, Nigeria

[6] Anikweze, I, C (2006). Need for entrepreneurship in Nigeria. Enugu: John Jocab's classic publishers ltd.

[7] Bayode, O.T. (2009). Snail Production Techniques: An opportunity for self-sustenance in the face of Economic Recession. Cedar Consult-Seminar Paper.

[8] Chinaka C. \& Wilson,K. E. (1995). Snail Production Techniques in Nigeria. Extension Bulletin No 108 (12)

[9] Deniz A., Hülya Ş. \& Ahmet A. (2019). Diseases in Land Snail Culture. $1^{\text {st }}$ International Conference on Environment, Technology and Management. 27-29 June, 2019. Retrieved from

https://www.researchgate.net/publication/335401437_DIS

EASES IN LAND SNAIL CULTURE/link/5dbbf57929

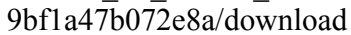

[10] Ekezie A. (2019). Skills Acquisition in Snail Farming: A Panacea for Entrepreneurship Development of Graduate Youths in Rivers State, Nigeria. Journal of Education and Practice Vol.10 (33) www.iiste.org ISSN 2222-1735 (Paper) ISSN 2222-288X (Online)

[11] Ekwu, S., (2016). Snail Farming. Risk Factors, Diseases and Conservation Practice in the Humid Tropics. Munich, GRIN Verlag, https://www.grin.com/document/358658 ISBN: 9783668431515

[12] Emevbore, E.A. \& Ademosum, A.A (1998) The nutritive value of the African Giant Snail, Archachatina Margination Animal production Research, 8 (2). 76-87

[13] Esak, K.O. and Takerhash, I.S. (1992). Snails as pest and food. Malaysian Journal of Economic Agriculture 59:359 367.

[14] Ezeani (2011). Effects of two edible fruits on the growth performance of African giant land snail. (Archachitina marginata Swainson). Journal of Agricultural and Biological Sciences 3(3): 26-29.

[15] Nkalo, H. U. (n.d). Snail Farming: Production, Utilization and Marketing. Retrieved from https://www.academia.edu/37269208/SNAIL FARMING _PRODUCTION_UTILIZATION_AND_MARKETING.d ocx

[16] Nnodim, A.U. \& Ekpo, S.U. (2019) Factors Constraining Commercial Farming of Snail among Farmers in Rural Areas of Rivers State. International journal of Rural Development, Environment and Health Research (IJREH) 3(5) https://dx.doi.org/10.22161/ijreh.3.5.1

[17] Nwarieji and Anene (2013). Entrepreneurial Skills Required by Small Scale Poultry Farmers in Orumba South. Unpublished Bsc Project. Department of Agricultural Education University of Nigeria, Nsukka

[18] Nwogor, A. U. (2015). Comparative Study on the Effect of Citrillus lanatus and Cucumis sativus on the Growth Performance of Archachatina marginata. American. 
Journal of Agriculture and Forestry Volume 3, Issue 4, July 2015, Pages: 135-139

[19] Obateru, T. (2012). Utilization of giant land snail (Archachatina marginata Swainson) in Oshimili South Local Government Area of Delta State. Unpublished B.Sc Project submitted to the Department of Forestry and Wildlife, Delta State University, Asaba Campus. 43p

[20] Odo C. (2016) My Snailry Guide. Enugu: Johnkens and Wiley Publication International Nig. Ltd.

[21] Ogba, E. I. \& Ndem J. U. (2016). Skills Needed by Secondary School Graduates for Breeding and Rearing of Giant African Land Snail (GALS) in Ebonyi State. Journal of Education and Practice Vol.7 (22). www.iiste.org ISSN 2222-1735 (Paper) ISSN 2222-288X (Online)

[22] Okonta, B. O (2012). Performance Of Giant African Land Snail Archachatina Marginata (Swainson) Fed With Selected Diets. Global Journal of Bio-science and Biotechnology., VOL.1 (2) 2012: 182-185

[23] Onuigbo C. C. (2015). Economics of Snail Production in Enugu East Agricultural Zone of Enugu State, Nigeria. $A$ Dissertation Submitted to the Department of Agricultural Economics, University of Nigeria, Nsukka in Partial
Fulfilment of the Requirements for the Award of Masters of Science (M.Sc) Degree in Agricultural Economics

[24] Scaglia, A. J. \& Karnwea, S. H. (2013). Improved Snail Farming (Farm Tech-Note). Forest Instrument Liberia

[25] Snail Word (2017). Facts about Snails. Retrieved from https://www.snail-world.com/snail-facts/

[26] Solomon, L. (2013). Special feasibility study report on snail farming in Bori, Rivers State, Nigeria. American Journal of Research Communication, 1 (4) 138-164.

[27] Umeh R. C. (2017). Entry Level Skills Required By Nce Graduates of Agricultural Education in Processing of Snail in Snail Farming Enterprise in South Eastern Nigeria. Multidisciplinary Journal of Research Development, 26 (2), $1-7$

[28] Ebenso I. E. (2002). Consumption and sales of Domesticated snail (Archachatina marginata) in Rural Southern Nigeria. Tropical Science, England 42:185-187.

[29] Effiong, E.O. (2005): Efficiency of production in selected livestock enterprises in Akwa Ibom State, Nigeria. Unpublished Ph.D thesis, Department of Agricultural Economics, Michael Okpara University of Agriculture, Umudike. 